\title{
EFEKTIVITAS PARTICIPATORY DESIGN DI KAMPUNG KOTA
}

\author{
Rusydina Sabila Fauzi \\ Mahasiswa Prodi Arsitektur, Fak. Teknik Departemen Teknik Arsitketur dan Perencanaan, \\ Universitas Gadjah Mada, Yogyakarta \\ e-mail: sabila.rusydina95@gmail.com \\ Ardhya Nareswari \\ Dosen Prodi Arsitektur, Fak. Teknik Departemen Teknik Arsitketur dan Perencanaan, \\ Universitas Gadjah Mada, Yogyakarta \\ e-mail: nares@ugm.ac.id
}

\begin{abstract}
ABSTRAK
Permasalahan dikampung kota tidak tersedianya ruang-ruang publik dan kepadatan yang mengakibatkan kerapatan bangunan rumah, penataan kampung yang tepat dapat menjamin keberlanjutan. Dalam menata kampung kota perlu partisipasi masyarakat sebagai perancang untuk memenuhi kebutuhan serta sesuai dengan tujuan yang sudah ditetapkan. Hal tersebut perlu adanya pengamatan dan penilaian efektivitas untuk mencapai dan memaksimalkan participatory design tersebut. Penelitian ini bertujuan melihat bagaimana efektivitas participatory design di kampung kota Pakuncen, Yogyakarta yang tidak memiliki ruang publik dikarenakan keterbatasan lahan. Metode penelitian menggunakan deskriptif kualitatif. Analisis kualitatif dilakukan untuk mendapatkan informasi terkait tahapan participatory design. Penilaian efektivitas menggunakan teori dari Duncan yang dikutip oleh Richard Steers melalui tiga parameter yaitu Pencapaian Tujuan, Integrasi dan Adaptasi. Hasil temuan dari penelitan ini menunjukan bahwa efektivitas participatory design di Kampung Pakuncen cukup terbilang efektiv. Hal ini disebabkan oleh tercapainya tujuan yang masyarakat butuhkan dan kepuasan masyarakat terhadap hasil dari pembangunan, namun jangka waktu yang dibutuhkan untuk meyakinkan warga cukup lama. Dilihat dari keunikan nya yaitu menabung seribu perhari untuk membangun balai pertemuan warga yang awalnya tidak dimiliki oleh masyarakat karna ketidak tersedianya lahan namun dengan semangat yang tinggi, keterlibatan masyarakat secara penuh dan aktifnya warga dalam mengikuti setiap proses diskusi dapat menentukan keberhasilan setiap proses dari participatory design ini.
\end{abstract}

Kata kunci : Efektivitas, Kampung Kota, Participatory Design,

\begin{abstract}
The problem in the urban village is unavailability of public spaces and density that effect the density of house buildings, proper village arrangement can ensure sustainability. In managing the urban village, it is necessary to have community participation as a designer and in accordance with the goals set. This requires observation and assessment to achieve and maximize the participatory design. This study aims to see
\end{abstract}

PAWON: Jurnal Arsitektur, Nomor 01 Volume VI, Januari - Juni Tahun 2022, ISSN 2597-7636 
how effective participatory design is in the village of Pakuncen, Yogyakarta which does not have public space due to limited land. The research method used is descriptive qualitative by analyzing the data using Moleang. The effectiveness assessment uses Duncan's theory cited by Richard Steers through three indicators, namely Goal Achieving, Integration and Adaptation. The findings of this research show that the effectiveness of participatory design in Pakuncen Village is quite effective. This is due to the achievement of the goals that the community needed and the community's satisfaction with the results of the development, but the period of time required to convince the people is quite long. Judging from its uniqueness, saving a thousand per day to build a hall, at first it was not owned by the community due to the unavailability of land but with high enthusiasm, fully community involvement and active participation of residents in each discussion process can determine the success of each participatory design.

\section{Keywords : Effectiveness, Participatory Design, Urban Village}

\section{PENDAHULUAN}

Meningkatnya kepadatan penduduk yang ada di Indonesia menimbulkan pembangunan kota meningkat pesat (Sofiyah, 2018). Perkembangan kota yang pesat memberikan dampak pada pemanfaatan oleh penghuni dalam ruang kota tidak sesuai dengan rencana tata kota. Hal tersebut mengakibatkan pertumbuhan kota tidak terkendali yang dapat membentuk kampung kota (Wirasmoyo, 2017). Kepadatan pada kampungkampung kota dapat dilihat dengan perbandingan minimnya ruang publik, sempit, dan lahan yang terbatas sehingga jarak antar bangunan yang cukup dekat (Nugroho, 2009). Penataan kampung yang tepat dapat mengembangan masyarakat yang lebih baik, pemanfaatan ruang berdampak baik dan menjamin keberlanjutan (Makhmud dkk., 2017).

Penataan kampung kota merupakan upaya dalam pelestarian sosial budaya memerlukan sebuah bentuk partisipasi masyarakat didalamnya. (Fahrudin, 2011) Hal ini guna meningkatkan kapasitas masyarakat dari beberapa aspek yaitu cara memecahkan permasalahan sosial, memanfaatkan dan mengembangkan sumber daya serta memenuhi kebutuhan dan keinginan masyarakat untuk alasan lebih baik (Muwifanindhita \& Idajati, 2019)

Dalam dunia rancangan, terdapat suatu pendekatan yang menggunakan masyarakat sebagai perancang untuk memenuhi kebutuhan masyarakat yang disebut dengan Participatory design (Putra G \& Zahro H, 2019). Pada perkembangannya arsitek berinisiatif melakukan perancangan agar masyarakat timbul rasa memiliki pada bangunan (Sofiyah, 2018). Penerapannya dimana pada prosesnya masyarakat diberi keluasan dalam mengambil keputusan dan didampingi dari mulai perancanaan hingga

PAWON: Jurnal Arsitektur, Nomor 01 Volume VI, Januari - Juni Tahun 2022, ISSN 2597-7636 
pembangunan. Proses participaory design memerlukan adanya diskusi antara pemerintah, desainer dan masyarakat. Hal ini penting sebagai tujuan dari participatory design untuk memenuhi harapan semua pihak (B.N.Sanders, 2002)

Fenomena yang melatar belakangi hal tersebut timbul Arsitek Komunitas yang berdedikasi untuk membimbing masyarakat untuk mengetahui permasalahan dan menemukan potensi-potensi seperti di kampung kota kemudian untuk lingkungan hidup dan pengembangan masyarakat yang lebih baik. Arsitektur komunitas menerapkan participatory design pada perancangan dan pembangunan bangunan publik (Sofiyah, 2018)

Adapun tujuan dan manfaat dari penerapan Participatory design (Arkomjogja, 2016):

1. Untuk menciptakan transformasi bangunan yang dimiliki masyarakat

2. Membantu mengembangkan, mendokumentasikan dan berbagi teknik yang berguna dalam meningkatkan partisipatif

3. Membantu memahami masalah secara bersama, penentuan prioritas, pencarian solusi serta sebagai langkah awal untuk dikembangkan oleh masyarakat.

Dalam memaksimalkan kebutuhan masyarakat dan mengutamakan kualitas serta hasil dari penerapan participatory design perlu adanya pengamatan untuk mencapai efektivitas participatory design di kampung kota. Efektivitas ini adalah untuk memanfaatkan sumber daya, sarana dan prasarana tertentu dalam mencapai tujuan dengan ketepatan waktu serta melihat bagaimana aktifnya anggota yang berpartisipasi dan sesuai dengan tujuan dan hasil yang sudah ditetapkan (Abdurahmat dalam Haekase dkk, 2020)

Berdasarkan deskripsi diatas, dalam memperbaiki kampung menjadi lebih baik, perlu adanya partisipasi masyarakat didalamnya. Masyarakat terlibat dalam perancangan sehingga dapat mencapai kebutuhan. Untuk memaksimalkan kebutuhan masyarakat dan hasil dari perancangan tersebut perlu adanya pengamatan. Berdasarkan latar belakang diatas penelitian ini guna untuk mengetahui bagaimana efektivitas penerapan participatory design di kampung kota dalam memenuhi kebutuhan masyarakat. Harapan dari penelitian ini agar bermanfaat dan dapat meningkatkan kualitas masyarakat. Selain itu diharapkan penelitian ini dapat menambah wawasan tentang efektivitas participatory design di kampung kota sebagai bahan rujukan dalam mengembangkan dan menilai suatu pembangunan kampung kota nanti.

PAWON: Jurnal Arsitektur, Nomor 01 Volume VI, Januari - Juni Tahun 2022, ISSN 2597-7636 


\section{TINJAUAN PUSTAKA}

Kampung kota ini dicirikan sebagai daerah padat penduduk, dengan kepadatan bangunan tinggi dan kurangnya infrastruktur yang memadai (Kusumaningdyah \& Lia, 2018) Committee on Environmental Health, 2009 mengatakan penyedian fasilitias ruang publik sangat penting dan merupakan sebuah kebutuhan yang harus dipenuhi untuk mendukung kegiatan bersama (Kusumaningdyah \& Lia, 2018).

Dalam mengatasi hal tersebut dengan penggunaan Participatory design yang melibatkan masyarakat muncul merupakan metode yang digunakan dalam menyelesaikan permasalahan berbasis komunitas khususnya dikampung kota. Hal ini dapat meningkatkan kemampuan kelompok komunitas untuk mencapai tujuan yang diinginkan seperti mengenali kekuatan/ potensi lingkunganya, kelemahan, peluang, dan ancaman, untuk memenuhi kebutuhan mereka dalam mendesain lingkungan (Henry Shanof dalam Nirawati, 2019).

\subsection{Kampung kota}

Kampung kota memiliki ciri khas dengan hubungan sosial antar manusia yaitu kekeluargaan dan keeratan yang mulai sulit ditemukan di perkotaan sehingga perlu untuk dilestarikan (Susanti \& Ikaputra, 2020).

Istilah kampung kota digunakan untuk menggambarkan wilayah di sekitar kota-kota besar, di mana di perkotaan dalam penggunaan lahan dan pemukiman hidup berdampingan dan bercampur secara intensif (Terry McGe dalam Hoa \& Hau 2021) karakteristuk kampung kota bercirikan dengan padat penduduk, kebutuhan infrastruktur tidak sepenuhnya terpenuhi, jalan yang sempit, dan bangunan saling berhadapan (Liu dkk, 2010).

Kondisi fisik dari kampung kota yaitu tidak layaknya lingkungan dan bentuk bangunan, tidak teratur, jarak bangunan yang sangat dekat dan sarana- prasarana yang tidak memadai, hubungan sosial antar masyarakat yang masih kuat (Sekar Ari, 2020). Dari hal tersebut dapat mempermudah komunikasi dalam bermusyawarah dan bergotong royong, guna untuk menemukan potensi-potensi pengembangan kampung kota menjadi lebih baik.

Berikut merupakan aspek-aspek yang akan ditinjau dalam meningkatkan kondisi dari berbagai upaya yang dilakukan adalah:

1. Latar Belakang Sejarah

Pendeskripsian ini merupakan penjelasan mengenai informasi awal mula gambaran kondisi fisik, dan sosial ekonomi pada kampung.

PAWON: Jurnal Arsitektur, Nomor 01 Volume VI, Januari - Juni Tahun 2022, ISSN 2597-7636 
2. Tahap awal

Pendeskripsian pada tahap awal menggambarkan situasi awal dari mulai perkembangan kampung dan berbagai kegiatan yang dilakukan masyarakat untuk mengelola kampungnya.

3. Perkembangan Lanjutan

Penjelasan mengenai bagaimana pelaksanaan dalam memperbaiki lingkungan seperti kegiatan sosial ekonomi untuk menunjang perbaikan kampung.

4. Kondisi saat ini

Mendeskripsikan gambaran situasi kampung pada masa ini dan memeperkirakan seberapa jauh kegiatan untuk menunjang dalam memperbaiki area permukiman serta mendukung pembangunan yang berkelanjutan.

5. Keterangan

Penjelasan ini menjabarkan mengenai kemungkinan yang terjadi untuk memperbaiki area permukiman diberbagai kampung dalam mendukung pembangunan yang berkelanjutan.

Hal ini dapat dilihat dari prinsip partisipatori yaitu memahami dari sejarah kampung dan melihat potensi potensi yang dapat mengembangkan kampung kota. Partisipasi masyarakat dibutuhkan dalam proses desain agar memenuhi kebutuhan yang ingin dicapai hal ini mempengaruhi salah satu faktor yaitu dari tingginya tingkat sosial antara masyarakat yang dapat menunjang keberhasilan.

\subsection{Participatory design}

Robertson and Simonsen mengatakan bahwa Participatory design adalah sebuah proses menyelidiki, memahami, merefleksikan, membangun, mengembangkan dan saling mendukung dalam sebuah komunitas. Anggotanya memiliki dua peran yaitu sebagai pengguna dan perancang yang mana pengguna mengartikulasikan apa tujuan yang ingin dicapai sedangkan perancang yaitu dengan memahami dan mempelajari lingkungannya (Cumbo \& Selwyn, 2021).

Partisipatory desain dapat meningkatkan kehidupan masyarakat dan membantu komunitas menjadi lebih baik (Ferguson \& Candy, 2014) Fase projek pada participatory design terbagi menjadi 3 bagian:

1. Planning and Relationships: Kegiatan untuk membantu Anda menentukan dan merencanakan proyek, dan membangun hubungan dengan pemangku kepentingan terkait

2. Design: Kegiatan yang berkaitan dengan mendefinisikan tantangan desain dan memfasilitasi kegiatan dengan komunitas lokal 
3. Monitoring and Evaluation: Kegiatan yang berkaitan dengan menentukan tujuan proyek, melacak kemajuan dan pengukuran keberhasilan.

Terdapat beberapa prinsip panduan utama untuk desain partisipatif meliputi (Ferguson \& Candy, 2014):

1. Arsitek bekerja secara langsung dengan masyarakat di lingkungan mereka sendiri untuk memahami langkah dan tools di lokasi;

2. Masyarakat, arsitek, dan pemangku kepentingan lainnya berpartisipasi secara setara sehingga dalam merancang, ide muncul dari berbagai latar belakang, dan pengambilan keputusan bersifat demokratis;

3. Menghargai semua jenis pengetahuan, terlepas dari apakah diperoleh melalui pelatihan profesional atau pengalaman hidup.

Dalam proses participatory design, terdapat beberapa tahapan yang dilakukan (Comprehensive Site Planning Handbook, 2011)

1. Melakukan observasi di lapangan dan menguasai kondisi lingkungan kampung

2. Melakukan analisa secara penuh terhadap komunitas dan kampung

3. Melakukan proses partisipatory design

4. Melakukan tahapan akhir pada rancangan

5. Menyusun perencanaan keuangan dan manajemen konstruksi

6. Melakukan implementasi, pengamatan yang dilakukan secara bersama dan belajar dari data empiris

7. Membagikan ilmu yang didapatkan dengan masyarakat luas.

Penggunaan participatory design dalam pembangunan ini bertujuan untuk mengembangkan sumber daya masyarakat serta menimbulkan rasa memiliki yang kuat pada bangunan/produk yang dihasilkan. Dalam prosesnya masyarakat turut berpartisipasi dalam setiap agenda yang dilaksanakan, ini ditujukan agar dapat memberdayakan masyarakat mulai dari menemukan masalah, mengambil keputusan, membangun, dan mengembangkan serta saling mendukung untuk mencapai tujuan yang diinginkan.

Sehingga dalam melakukan Participatory design penting untuk menggunakan langkah-langkah berikut yaitu:

1. Perencanaan (survey dan mengenali permasalahan dan potensi yang ada)

PAWON: Jurnal Arsitektur, Nomor 01 Volume VI, Januari - Juni Tahun 2022, ISSN 2597-7636 
2. Perancangan (mengklasifikasikan ide dan pemikiran dalam bentuk desain hingga terwujud desain akhir)

3. Implementasi (menyusun RAB, perencanaan keuangan dan manajemen konstruksi)

4. Evaluasi (mengukur keberhasilan dari proyek, dan berbagi pengalaman)

\subsection{Konsep Efektivitas}

Pengertian efektivitas adalah memanfaatkan sumber daya yang ada, sarana-prasarana dalam kuantitas tertentu yang sudah ditetapkan untuk menghasilkan sejumlah barang dan jasa yang akan dilaksanakan kegiatannya (Siagian dalam Sumolang 2017).

Selanjutnya pengertian efektivitas merupakan lingkupan upaya suatu kegiatan didalam suatu sistem yang memiliki sumber daya serta sarana dan prasarana tertentu dalam memenuhi target dan tujuan tanpa mengurangi sedikitpun jalan dan sumber daya itu sendiri serta tanpa memberikan paksaan pada pihak penyelenggara (Steers dalam Sumolang 2017).

Menurut Richard M. Steers yang mengutip pendapat dari Duncan mengenai tolak ukur efektivitas dalam Duncan. Efektivitas Organisasi. 1985. berikut (Haekase dkk, 2020):

1. Pencapaian Tujuan

a. Periode waktu dalam pencapaiannya ditentukan,

b. Tujuan pencapaian kongkret (nyata),

c. Dasar hukum.

2. Integrasi

a. Melakukan tahapan secara pasti

b. Mengikuti jalannya kegiatan sosialisasi.

3. Adaptasi

a. Meningkatkan kapabilitas

b. Sarana dan prasarana

\section{METODE PENELITIAN}

\subsection{Lokasi Penelitian}

Lokasi penelitian ini berada dikampung Pakuncen, Wirobrajan, Yogyakarta yang terletak di pinggiran sungai Winongo. Kampung Pakuncen meliputi RW 4,5,6,7,8 (RT 16 sampai dengan RT 38) Kampung Pakuncen terkhusus RT 38 merupakan salah satu desa yang tidak memiliki ruang publik sebagai balai pertemuan warga dan tidak ketersediannya lahan.

PAWON: Jurnal Arsitektur, Nomor 01 Volume VI, Januari - Juni Tahun 2022, ISSN 2597-7636 
Kampung Pakuncen khususnya RT 38 ini menggunakan penerapan Participatory design dalam menata kampungnya.

Kondisi demografi berdasarkan pendataan yang dilakukan pada tahun 2013 jumlah kepala keluarga sebanyak 57 KK yang terdapat di RT 38. Mata pencaharian warga cukup beragam seperti PNS, Pedagang, karyawan swasta, dan buruh harian lepas. Pedagang merupakan pekerjaan dominan yang terdapat di kampung Pakuncen. Tingkat Pendidikan oleh penduduk yang tamat SMA/sederajat. Adapun lokasi dari kampung Pakuncen ini disajikan pada gambar dibawah ini:
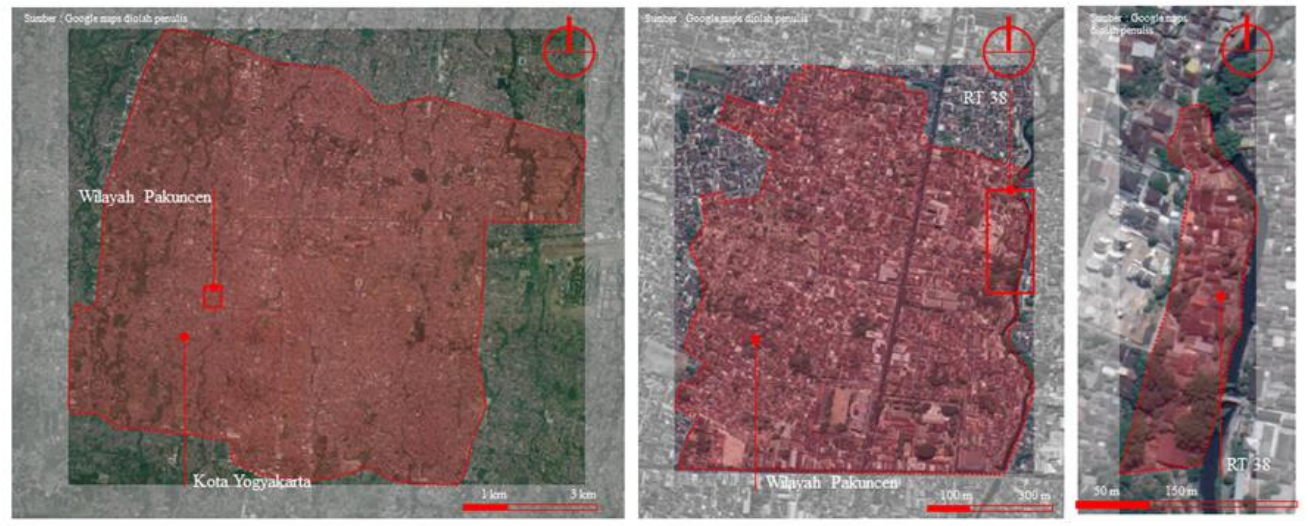

Gambar. 1

Lokasi penelitian

Sumber: Google maps diolah penulis, 2020

\subsection{Pengumpulan Data}

Metode penelitian yang diterapkan adalah deskriptif-kualitatif dengan cara mencari data diperoleh dari hasil wawancara dengan beberapa informan, observasi lapangan dan dokumentasi. Kemudian dalam prosesnya menggunakan kajian literatur. Informan berjumlah 4 orang yang terdiri dari 2 koordinator lapangan pengerjaan proyek, ketua RW sebagai anggota forum dan salah satu warga selaku partisipan. Wawancara yang dilakukan tidak terstruktur hanya berdasarkan pemahaman informan yang ikut berpartisipasi dan peneliti.

\subsection{Metode Analisa}

Analisa data dengan menggunakan teknik Moleong (Haekase dkk, 2020) mengemukakan yaitu pengumpulan data dengan mencari secara objektif. Wawancara dilakukan untuk mendapat informasi terkait tahapan participatory design. Wawancara ditujukan kepada narasumber sebagai pelaksana dan pengguna yang terdampak langsung dari participatory design, kemudian data dikumpulkan dan direduksi dengan merangkum hasil catatan observasi lapangan, wawancara dan dokumentasi yang relevan

PAWON: Jurnal Arsitektur, Nomor 01 Volume VI, Januari - Juni Tahun 2022, ISSN 2597-7636 
terkait participatory design di kampung kota. Lalu menyajikan data dengan menyusun kumpulan informasi dalam bentuk teks naratif untuk menjelaskan bagaimana proses participatory design yang terjadi dari data tersebut diolah berdasarkan teori-teori yang dikemukan oleh untuk memperoleh gambaran yang jelas. Verifikasi dan kesimpulan terkait efektivitas participatory design yang dilakukan dikampung kota diharapkan memenuhi kebutuhan dari pengguna dan dapat mengembangkan kualitas dan sumber daya yang ada.

Efektivitas akan dianalisis berdasarkan hasil wawancara dan observasi lapangan. Hasil analisis tersebut akan menghasilkan efektiv atau tidaknya participatory design. Efektiv atau tidak akan dinilai berdasarkan variabel teori oleh Duncan yang dikutip Richard M. Steers bahwa penilaian efektivitas berdasarkan pencapaian tujuan, integrasi dan adaptasi. Diagram tahapan penelitian disajikan digambar berikut:

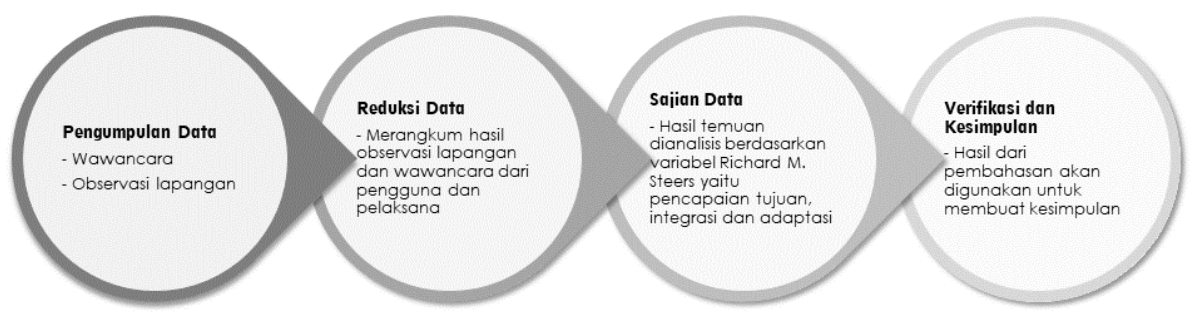

Gambar. 2

Diagram tahapan penelitian

Sumber: (Haekase dkk., diolah penulis 2021)

\section{HASIL DAN PEMBAHASAN}

\subsection{Participatory design di Kampung Pakuncen}

Dalam mendiskripsikan kampung yang meningkatkan kondisi melalui berbagai upaya yang dilihat dari aspek-aspek:

Tabel 1.

Profil Kampung Kota

\begin{tabular}{llllll}
\hline Kampung & $\begin{array}{c}\text { Latar } \\
\text { Belakang } \\
\text { Sejarah }\end{array}$ & Tahap Awal & $\begin{array}{c}\text { Perkembangan } \\
\text { Lanjutan }\end{array}$ & $\begin{array}{c}\text { Kondisi } \\
\text { Saat Ini }\end{array}$ & Keterangan \\
\hline Pakuncen, & Merupakan & Terdapat & Masyarakat & Warga & Berpotensi \\
Wirobrajan, & kampung & bantuan & bergotong & memiliki & sebagai \\
Yogyakarta & yang tidak & dari Arkom & royong untuk & tempat & kampung \\
& memiliki & sebagai & membangun & berkumpul & percontohan \\
& wadah/tempat & fasilitator & balai bambu & yang layak & dalam \\
& berkumpul, & untuk & mulai dari & dan & partisipasi \\
& lahan yang & menemukan & menuangkan & dibangun & masyarakatnya \\
& terbatas & potensi- & ide-de dan & diatas & \\
& potensi & membangun & drainase & \\
\hline
\end{tabular}

PAWON: Jurnal Arsitektur, Nomor 01 Volume VI, Januari - Juni Tahun 2022, ISSN 2597-7636 


kampung
yang dapat
dimanfaatkan
melalui
participatory
design

design

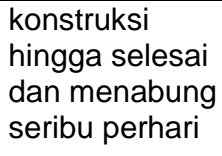

kota.

Menjadi

bahan

percontohan

untuk diteliti

oleh

mahasiswa

dari luar dan

dalam negri

Sumber: Penulis, 2021

Prinsip panduan utama desain partisipatif dikampung kota meliputi (Ferguson \& Candy, 2014):

1. Arsitek komunitas (Arkom Yogya) sebagai fasilitator mendampingi masyarakat dalam memahami permasalahn dan potensi kampung;

2. Pengguna yaitu warga RT 38 , dan pemangku seperti ketua RT dan ibu-ibu PKK serta Arkom berpartisipasi dari tahap awal hingga akhir. Partisipasi berupa ide-ide desain dan turut andil dalam pembangunan.;

3. Semua hak suara yang dikeluarkan berupa opini-opini didengarkan dalam setiap diskusi, klasifikasi desain dan sampai selesai.

Participatory design penting untuk menggunakan langkah-langkah berikut yaitu: (Comprehensive site planning handbook, 2011; Ferguson \& Candy, 2014)

1. Perencanaan (melakukan pemetaan kampung, menemukan masalah yaitu tidak memiliki tempat/wadah berkumpul yang cukup besar dikarenakan keterbatasan lahan dan mencari potensi lahan yang bisa digunakan yaitu membangun balai bambu diatas drainase kota. Pencarian solusi dengan memulai tabungan warga 1000/hari.

2. Perancangan (warga didampingi oleh Arkom sebagai fasilitator mengungkapkan ide-ide dan kebutuhannya dalam merancang balai bambu. Kemudian rancangan diklasifikasinya ke $3 d$ dengan hasil revisi juga disesuaikan dengan kondisi warga. Pembuatan maket serta RAB dilakukan oleh warga)

3. Implementasi (pembagian tugas dilakukan oleh seluruh warga RT 38, pengerjaan dilakukan pagi, siang, malam secara bergantian. Pembangunan balai bambu didampingi oleh tukang konstruksi bambu.)

4. Evaluasi (pengalaman selama pembangunan balai bambu didokumentasikan dan sharing melalui website. Aktifnya

PAWON: Jurnal Arsitektur, Nomor 01 Volume VI, Januari - Juni Tahun 2022, ISSN 2597-7636 
penggunaan balai bambu sehingga adanya jadwal perawatan berkala pada bangunan)

\subsection{Efektivitas Participatory design di Kampung Pakuncen}

Analisis penilaian efektivitas menggunakan teori oleh Duncan yang dikutip Richard M. Steers terkait kriteria efektivitas, sebagai berikut Duncan. Efektivitas Organisasi. 1985. Hal. 53 (Haekase dkk., 2020):

\section{Pencapaian Tujuan}

Hasil dari penelitian berdasarkan dari hasil wawancara dengan beberapa informan dan kuesioner dapat dikatakan efektiv karena telah mencapai tujuan yang sudah ditetapkan sebelumnya. Setiap proses participatory design dari mulai awal perencanaan hingga tahap evaluasi sudah mengikuti seluruh indikator sehingga dapat dinyatakan tujuan sudah tercapai. Pertama, sudah dianggap efektiv dikarenakan sudah memenuhi kebutuhan masyarakat untuk mempunyai ruang publik sebagai balai pertemuan warga. Kedua, masyarakat didampingi oleh Arkom untuk dibekali pengetahuan bagaimana cara menganalisis kampung, mendesain dan mengembangkan sumber daya masyarakat itu sendiri. Ketiga, masyarakat juga didampingi oleh ahli bambu yang dapat memberikan bekal kepada masyarakat untuk merawat balai agar digunakan jangka panjang.

Waktu yang sudah ditentukan dalam pembangunan ini cukup singkat hanya memakan waktu kurang lebih sebulan dikarenakan warga bergantian pagi siang dan malam dalam mengerjakan pembangunan balai warga, namun pada saat tahap awal perencanaan memakan waktu yang cukup lama untuk meyakinkan warga. Proses participatory design dilakukan secara bertahap, dimulai dari menganalisis kampung, mendesain bangunan hal ini bertujuan masyarakat mengikuti seluruh prosesnya dan dapat meningkatkan kemampuan masyarakat. Berdasarkan hasil wawancara, masyarakat mengakui bahwa masyarakat yang ikut berpartisipasi dalam pembangunan dapat menimbulkan rasa memiliki pada bangunan sehingga masyarakat lebih peduli dan merawat bangunan tersebut, selain itu juga dapat meningkatkan kemampuan warga serta keberhasilan dari participatory design ini dapat mengundang peneliti dari lokal dan mancanegara untuk meneliti keunikan dari hanya dengan menabung seribu perhari dapat membangun balai bambu. Adapun proses tahapan awal dari mulai menabung 1000/perhari yang dilakukan warga, keterlibatan warga dalam proses pembangunan balai bambu secara bergantian dan begotong royong hingga selesainya pembangunan balai pertemuan warga yang dinamakan balai bambu mawar disajikan pada gambar berikut: 


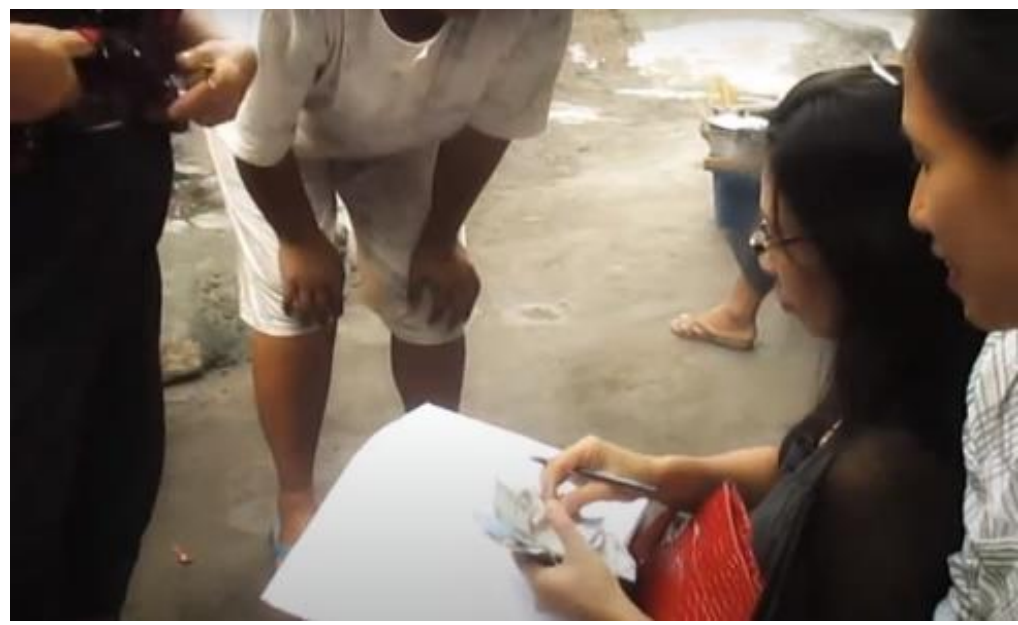

Gambar. 3

Proses mengumpulkan tabungan balai bambu Sumber: Dokumentasi warga, 2013

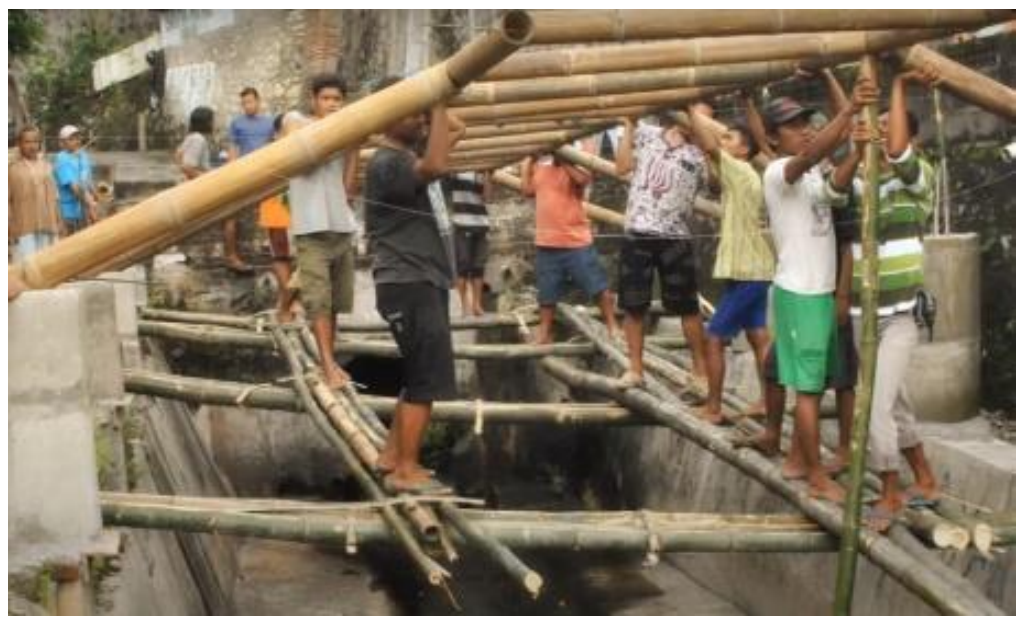

Gambar. 4

Proses pembangunan balai bambu Sumber: Dokumentasi warga, 2013

PAWON: Jurnal Arsitektur, Nomor 01 Volume VI, Januari - Juni Tahun 2022, ISSN 2597-7636 


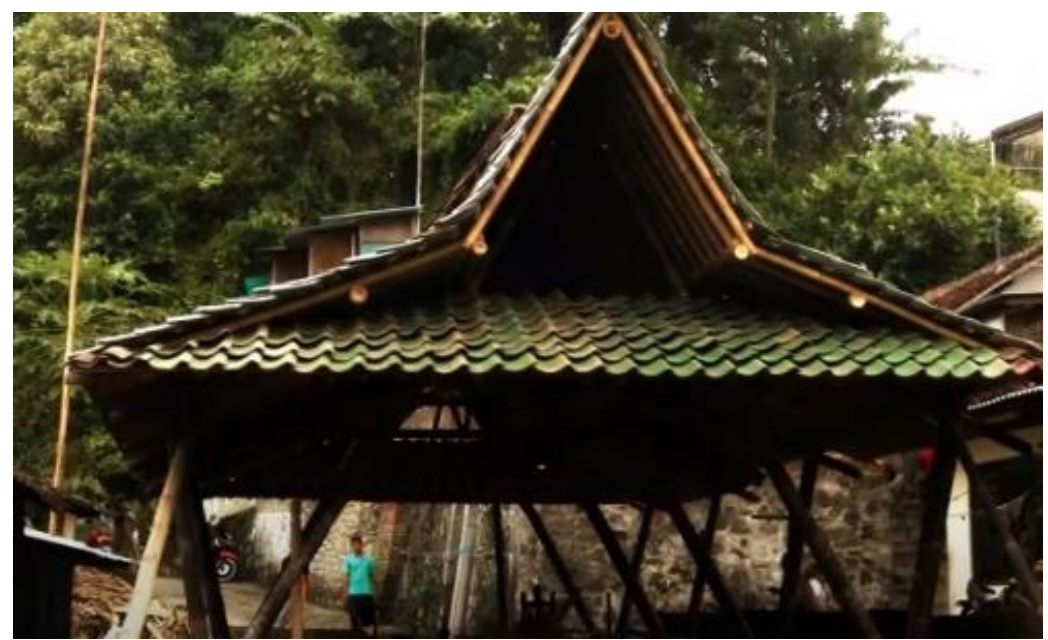

Gambar. 5

Balai bambu kampung Pakuncen

Sumber: Dokumentasi warga, 2013

2. Integrasi

Komunikasi yang dilakukan antar masyarakat untuk menyukseskan pembangunan ini sudah efektiv, komunikasi berupa sosialisasi dengan mengajak masyarakat berdiskusi menemukan apa saja yang dibutuhkan masyarakat. Sosialisasi dilakukan berulang kali untuk memberikan informasi dan pemahaman yang matang agar masyarakat nantinya tidak ada kesalahpahaman.

\section{Adaptasi}

Adaptasi memiliki dua parameter indikator, yaitu meningkatkan kemampuan dan sarana dan prasarana. Dalam adaptasi yaitu peningkatan dalam kemampuan, masyarakat cukup aktif dan berpartisipasi dalam mendesain, membuat RAB dan membuat maket dari hasil perhitungan RAB serta hasil wawancara warga ikut diajarkan bagaimana memilih bambu dan cara perawatan bambu oleh ahli bambu, hal ini dapat meningkatkan kemampuan warga karena diajarkan langsung oleh ahlinya.

Pada indikator sarana dan prasarana sudah efektiv, berdasarkan hasil wawancara pada informan hal ini didukung dengan partisipasi warga yang selalu meluangkan waktu, tempat dan tenaga nya untuk mengikuti setiap proses pembangunan balai. Dana tersedia dari tabungan warga yang dikumpulkan 1000/hari serta mendapat pinjaman dari Arkom. Terdapat juga bantuan material bangunan dari warga sendiri sehingga jangka waktu yang dibutuhkan dalam pembangunan cukup singkat.

PAWON: Jurnal Arsitektur, Nomor 01 Volume VI, Januari - Juni Tahun 2022, ISSN 2597-7636 
Kesimpulan dari hasil wawancara dari beberapa informan, warga dapat meningkatkan kemampuan dan percaya dirinya untuk dapat menuangkan ide-ide desain nya untuk membangun kampungnya menjadi lebih baik. Hasil dari pembangunan tersebut dapat bermanfaat oleh warga itu sendiri dan adanya jadwal rutin perawatan agar bangunan tahan lama karena adanya rasa tanggung jawab dari warga sudah membangun dari awal hingga akhir serta pengalaman selama membangun dibagikan melalui situs web sebagai pembelajaran.

\section{KESIMPULAN}

Berdasarkan hasil kajian terkait penerapan Participatory design dikampung kota dapat disimpulkan bahwa penggunaan participatory design di kampung kota efektiv. Hal ini juga disebabkan oleh semangat dan komunikasi antar warga yang cukup aktif agar pembangunan ini berhasil. Keberhasilan dalam projek ini dinilai efektiv karena setiap prosesnya dilakukan dengan niat dan disiplin yang kuat dari setiap warga dan sesuai dengan kebutuhan serta kepuasan warga dengan hasil yang didapatkan.

\section{DAFTAR PUSTAKA}

Arkomjogja. (2016). Tujuan dan Manfaat Participatory Design. Retrieved October 10, 2020, from arkomjogja.or.id website:

http://arkomjogja.or.id/portfolio-item/arkomjogja-methods/

B.-N.Sanders, E. (2002). From user-centered to participatory design approaches. 1-8. https://doi.org/10.1201/9780203301302.ch1

Comprehensive site planning handbook. (2011). Comprehensive site planning.

Cumbo, B., \& Selwyn, N. (2021). Using participatory design approaches in educational research. International Journal of Research and Method in Education, O(0), 1-13. https://doi.org/10.1080/1743727X.2021.1902981

Fahrudin, A. (2011). Pemberdayaan Partisipasi dan Penguatan Masyarakat. Bandung: Humaniora.

Ferguson, K., \& Candy, S. (2014). Participatory Design Handbook: a Collaborative Approach To Address Community Based Challenges. 65. Retrieved from http://kateferguson.org/documents/Participatory-DesignHandbook.pdf

Haekase, Y., Nursalam, N., \& Toda, H. (2020). The effectiveness VillageOwned Enterprises (BUMDes) Sehati in Nekmese Village Amarasi SubDistrict, South Kupang Regency. Journal of Sustainable Tourism and Entrepreneurship, 1(3), 217-230. https://doi.org/10.35912/joste.v1i3.277 
Hoa, T. Q., \& Hau, P. T. (2021). Understanding the concept of urban village in Hanoi city, Vietnam: Social - Spatial - Economic interactions with surrounding urban areas. Journal of Science and Technology in Civil Engineering (STCE) - NUCE, 15(1), 132-149.

https://doi.org/10.31814/stce.nuce2021-15(1)-12

Kusumaningdyah, N. ., \& Lia, S. P. (2018). The Techniques of Participatory Design for Inclusive Public Space Provision in Kampung Kota of Surakarta. SHS Web of Conferences, 41, 07007. https://doi.org/10.1051/shsconf/20184107007

Liu, Y., He, S., Wu, F., \& Webster, C. (2010). Urban villages under China's rapid urbanization: Unregulated assets and transitional neighbourhoods. Habitat International, 34(2), 135-144.

https://doi.org/10.1016/j.habitatint.2009.08.003

Makhmud, D. F., Nuhasanah, F., Utamai, I. U., Khansa, S., Radnawati, D., \& Syahadat, R. M. (2017). Mewujudkan Kampung Bandan Sebagai Kampung Kota Berkelanjutan Menggunakan Pendekatan Asian New Urbanism. Jurnal Arsitektur, Bangunan, \& Lingkungan, 6(3), 91-100. Retrieved from http://publikasi.mercubuana.ac.id/index.php/virtuvian/article/view/1540

Muwifanindhita, M. B., \& Idajati, H. (2019). Identifikasi Faktor yang Memengaruhi Partisipasi Masyarakat Kampung Ketandan sebagai Kampung Wisata di Surabaya. Jurnal Teknik ITS, 7(2). https://doi.org/10.12962/j23373539.v7i2.32440

Nirawati, M. A., Hardiana, A., \& Utomo, R. P. (2019). Participatory Design Designing with Kids in Kampung Sewu - Surakarta. 156(Senvar 2018), 45-51. https://doi.org/10.2991/senvar-18.2019.8

Nugroho, A. C. (2009). Kampung kota sebagai sebuah titik tolak dalam membentuk urbanitas dan ruang kota berkelanjutan. Jurnal Rekayasa.

Putra G, A., \& Zahro H, Z. (2019). Desain Partisipasi Dalam ruang Publik, Ruang komunal Sosial Dalam Kampung Heritage TawangsariSebagai Salah Satu Bentuk Aplikasi Unsur Keberlanjutan Sosial. PAWON: Jurnal Arsitektur, III, 25-36.

Sekar Ari, U. (2020). ON-SITE UPGRADING : STRATEGI MEMENUHI ADEQUATE HOUSING Pendahuluan Metode Kajian Teori. 18, 65-76.

Sofiyah, F. (2018). Kajian metode perancangan partisipatori pada arsitektur. Universitas Katolik Parahyangan. 
Sumolang, K. (2017). EFEKTIVITAS PROGRAM CERDAS COMMAND CENTRE PADA PENGADUAN PUBLIK. Jurnal Politico, 1-13.

Susanti, A. D., \& Ikaputra, I. (2020). Morfologi Urban Artefak Kampung Kota. MARKA (Media Arsitektur Dan Kota) : Jurnal Ilmiah Penelitian, 4(1), 1726. https://doi.org/10.33510/marka.2020.4.1.17-26

Wirasmoyo, W. (2017). OPTIMASI LAHAN TERLANTAR MENJADI RUANG PUBLIK DI KAMPUNG KOTA; Studi Kasus: Lahan Terlantar Kampung Badran RW. 09, Yogyakarta. Jurnal Arsitektur KOMPOSISI, $11(5), 217$. https://doi.org/10.24002/jars.v11i5.1295 